\title{
Implementasi Landasan Religius dalam Kegiatan Bimbingan dan Konseling Sebagai Upaya Penanganan Dampak Masa Puber
}

\author{
Rochanah \\ IAIN Kudus, Jawa Tengah, Indonesia \\ hana@stainkudus.ac.id
}

\begin{abstract}
Abstrak
Masa puber merupakan masa pertumbuhan dan perubahan yang pesat. Masa puber ditandai oleh pertumbuhan pesat dan perubahan mencolok dalam proporsi tubuh. Perubahan-perubahan ini menimbulkan keraguan, perasaan tidak mampu dan tidak aman, dan dalam banyak kasus mengakibatkan perilaku yang kurang baik. Untuk mengantisipasi dampak buruk pada masa puber, maka perlu adanya peran dalam bimbingan dan konseling. Tujuan dalam penelitian ini adalah untuk mengetahui bagaimana implementasi landasan religious dalam kegiatan bimbingan dan konseling sebagai penanganan dampak masa puber. Rumusan masalah yang diangkat dalam penelitian ini adalah 1) implementasi landasan religious dalam bimbingan dan konseling, dan 2) implementasi landasan religious dalam kegiatan bimbingan dan konseling dalam menangani dampak pubertas. Metode yang digunakan dalam penelitian ini adalah metode studi pustaka, yakni pengumpulan data dan informasi dengan menelaah sumber-sumber tertulis seperti jurnal ilmiah, buku referensi, literatur, ensiklopedia, karangan ilmiah, serta sumber-sumber lain yang terpercaya baik dalam bentuk tulisan atau dalam format digital yang relevan dan berhubungan dengan objek yang diteliti. Berdasarkan uraian dalam pembahasan, hasil yang dapat disimpulkan adalah implementasi landasan religious dalam menghadapi masa puber siswa adalah dengan kembali pada Al Qur'an dan Hadits yang dijadikan sebagai pedoman dalam agama Islam.
\end{abstract}




\title{
Implementasi Landasan Religius dalam Kegiatan Bimbingan ...
}

Kata kunci: landasan religious; bimbingan dan konseling; masa puber.

\begin{abstract}
Puberty is a period of rapid growth and change. The puberty is characterized by rapid growth and striking changes in body proportions. These changes create doubts, feelings of inadequacy and insecurity, and in many cases result in unfavorable behavior. To anticipate the adverse effects on puberty, it is necessary to have a role in guidance and counseling. The purpose of this research is to know how the implementation of religious foundation in guidance and counseling activity as handling impact of puberty. The formulation of the problems in this research are 1) the implementation of religious foundations in guidance and counseling, and 2) the implementation of religious foundations in guidance and counseling activities in dealing with the effects of puberty. The method used in this study is the literature study method, which is collecting data and information by examining written sources such as scientific journals, reference books, literature, encyclopedias, scientific writings, as well as other reliable sources in written or in digital form relevant and related to the object studied. Based on the description in the discussion, the result which can be concluded is the implementation of religious foundations in facing puberty students is by returning to the Qur'an and Hadith which serve as a guidance in Islam.
\end{abstract}

Keywords: the religious foundation; guidance and counseling; puberty.

\section{A. Pendahuluan}

Menurut Djahwat Dahlan (2001:101) bahwa "remaja yang sedang mengalami proses transisi atau pubertas memiliki ciri-ciri dalam pertumbuhan fisik, psikis dan sosialnya". Pada umumnya remaja mengalami berbagai kesulitan dan masalah dalam melakukan penyesuaian diri terhadap dirinya dan lingkungan pada masa pubertas. Perubahan-perubahan fisik menyebabkan kecanggungan bagi remaja karena ia harus menyesuaikan diri dengan perubahanperubahan yang terjadi pada dirinya (Sarlito Wirawan Sarwono, 2001:52). Ini artinya, pada masa remaja akan mengalami berbagai 
kondisi yang berbeda selama melewati masa puber, baik dalam hal fisik maupun dlam hal psikis. Menurut Elizabeth B Hurlock (1980:185) bahwa akan terjadi perasaan ragu, ketidakmampuan dan perilaku tidak baik ketika terjadi perubahan-perubahan melewati masa puber. Oleh karenanya, remaja seharusnya mampu menyesuaikan dirinya dengan segala perubahan yang terjadi pada masa puber sehingga remaja mencapai kepuasan terhadap diri dan lingkungan (Suryani dkk, 2013:136). Sebagai upaya mengantisipasi dampak pubertas tersebut, maka diperlukan sebuah tindakan dalam menanganinya, yakni melalui kegiatan bimbingan dan konseling yang berlandaskan agama. Hal demikian karena agama menjadi suatu yang tidak terpisahkan dari kehidupan manusia.

Manusia memiliki kedudukan yang sangat mulia dan tinggi dalam agama Islam. Dengan keistimewaan dan kemuliaan yang dianugerahkan kepada manusia semenjak lahir (fitrah), manusia diberi amanah oleh Allah untuk menjadi khalifah di muka bumi ini. Namun fitrah yang telah dibawanya tersebut akan terhenti manakala tidak dibarengi bimbingan dan pengajaran. Dengan perjalanan perkembangan fitrah manusia, akan menghadapi berbagai permasalahan. Dengan pendekatan agama, konselor akan dapat mengatasi masalah yang dihadapi klien. Agama mengatur segala aspek kehidupan manusia untuk mewujudkan ketenteraman, dan kedamaian batin manusia (Sutima, 2013: 162-163). Agama yang pada akhirnya menjaga fitrah yang dibawa manusia sejak lahir agar tetap terjaga sesuai fitrah aslinya. Hal ini sebagaimana diungkapkan oleh MSurya bahwa:

“...agama menentukan dalam proses penyesuaian diri. Hal ini diakui oleh ahli klinis, psikiatris, pendeta, dan konselor bahwa agama adalah faktor penting dalam memelihara dan memperbaiki kesehatan mental. Agama memberikan suasana psikologis tertentu dalam mengurangi konflik, frustasi, dan ketegangan lainnya, dan memberikan suasana damai dan tenang (Yusuf Dan A. Juntika Nursihan, 2009: 139-140)."

Agama merupakan sumber nilai, kepercayaan dan pola-pola tingkah laku yang akan memberikan tuntunan bagi arti, tujuan dan 


\section{Implementasi Landasan Religius dalam Kegiatan Bimbingan ...}

kestabilan hidup umat manusia. Kehidupan yang efektif menuntut adanya tuntunan hidup yang mutlak. Usaha dan doa merupakan medium dalam agama untuk menuju ke arah kehidupan yang berarti. Agama seharusnya melekat dalam setiap bidang kehidupan manusia karena ketika mengesampingkan agama, maka pada akhirnya akan menimbulkan dampak yang buruk dalam bidang tersebut. Demikian halnya, perkembangan ilmu pegetahuan dan teknologi serta praktikpraktik kehidupan politik dan ekonomi yang tidak berlandaskan moral agama telah menyebabkan berkembangnya gaya hidup materialistik dan hedonistik. Dampak lebih parahnya adalah terjadinya dekadensi moral atau pelecehan nilai-nilai agama di semua kalangan, baik dewasa, remaja maupun anak-anak (Yusuf Dan A. Juntika Nursihan, 2009: 140). Oleh karenanya, agama hendaknya selalu melekat dalam diri manusia dlm segala aktifitas yang dijalaninya.

Menurut Zakiyah Daradjat, satu diantara peran agama adalah sebagai terapi (penyembuhan) bagi gangguan kejiwaan. Manakala pemeluk agama mampu mengamalkan agama dalam kehidupan sehari-hari maka akan dapat membentenginya dari kejahatan gangguan kejiwaan dan sekaligus mengembalikan kesehatan jiwa bagi yang merasakan kegelisahan. Karenanya, semakin dekat seorang hamba dengan tuhannya, semakin memperkuat ibadahnya maka akan semakin tenteram pula jiwanya, serta semakin mampu menghadapi kesukaran dan permasalahan dalam hidup. Dan sebaliknya. Dari sini, dapat disimpulkan bahwa agama mampu memberikan ketenteraman jiwa bagi pemeluknya yang mengamalkan agamanya (Yusuf Dan A. Juntika Nursihan, 2009: 139).

\section{B. Pembahasan}

\section{Landasan Religious}

Landasan religious dalam bimbingan dan konseling memposisikan klien sebagai makhluk ciptaan Allah dengan segenap kemuliaan yang Allah berikan kepadanya. Oleh karenanya, dalam konselor memberikan bimbingan dan konseling kepada klien harus dengan penuh kemuliaan juga. Namun demikian, perbedaan keyakinan agama pada tiap klien, maka konselor harus bersikap hatihati dan bijak dalam menerapkan landasan religious tersebut. 
Implementasi layanan bimbingan dan konseling dalam Islam haruslah meujuk pada ajaran agama Islam, yakni al Qur'an dan hadits. Ini artinya, bagi klien yang menganut keyakinan agama Islam, maka pelayanan bimbingan dan konseling harus sesuai/merujuk pada keyakinan agamanya, tidak boleh bertentangan dengan agama yang dianutnya (Tohirin, 2011: 97-98). Jadi, konselor harus mengenal lebih dulu keyakinan agama yang dianut dan diyakini oleh klien, untuk kemudian konselor menyesuaikan dengan agama yang dianutnya tersebut.

Pada dasarnya, tujuan yang hendak di capai dalam penerapan landasan religious bimbingan dan konseling adalah ingin menempatkan siswa sebagai makhluk Tuhan dengan segenap kemuliaannya. Landasan religious adalah sebagai upaya mengintegrasikan nilia-nilai agama dalam proses bimbingan dan konseling (Yusuf Dan A. Juntika Nursihan, 2009: 133). Dari sini dapat kita ambil kesimpulan bahwasannya agama dijadikan sebagai landasan dalam proses bimbingan dan konseling dalam menghadapi suatu problematika kehidupan. Dalam tulisan ini, agama dijadikan sebagai landasan dalam menangani problematika dampak dari masa puber.

Agama sebagai bentuk keyakinan manusia terhadap sesuatu yang besifat adikodrati menyertai manusia dalam kehidupan yang luas. Agama memiliki nilai dalam kehidupan manusia baik bagi diriya sendiri maupun hubungannya dengan kehidupan masyarakat. Agama juga berdampak pada kehidupan sehari-hari. Karenanya, secara psikologis agama berfungsi sebagai motif intrinsik dan motif ektrinsik.dan motif yang didorong keyakinan agama dinilai memiliki kekuatan yang mengagumkan dan sulit ditandingi oleh keyakinan nonagama, baik doktrin maupun ideologi yang bersifat profan (Jalaludin, 2012, hlm. 317-318).

Pengintegrasian nilai-nilai agama dalam proses bimbingan dan konseling sepatutnya mendapat tempat dalam praktik-praktik konseling, hal ini sebagaimana yang dikemukakan oleh Marsha Wiggins Frame sebagai berikut: 


\section{Implementasi Landasan Religius dalam Kegiatan Bimbingan ...}

a. Mayoritas orang Amerika meyakini Tuhan dan mereka banyak melakukan ritual ibadah mereka sesuai dengan keyakinan yang mereka anut. Hal ini menunjukkan bahwa klien memiliki latar belakang agama yang membentuk sikap, keyakinan, perasaan dan tingkah lakunya.

b. Terdapat tumpang tindih dalam nilai dan tujuan antara konseling dan agama, misalnya terkait fungsinya sebagai upaya membantu individu agar dapat mengelola berbagai kesulitan hidupnya. Dengan demikian, dibutuhkan pengakuan profesi konseling terhadap nilai-nilai agama klien dan konselor. Ini artinya, dalam proses bimbingan dan konseling tidak boleh mengabaikan nilainilai agama karena antara nilai dan tujuan konseling dan agama saling berkesinambungan antara satu denga lainnya.

c. Keyakinan bahwa beragama berkontribusi positif terhadap kesehatan mental. Agama dapat digunakan oleh klien sebagai upaya menunjang kesehatan mental.

d. Agama mampu mengubah pola berfikir/ mindset yang berkembang di akhir abad 20. Gerakan postmodern telah menjembatani perbedaan antara ilmu dan agama dan telah mengintegrasikan kedua dimensi tersebut ke dalam pendekatan psikoterapi (konseling) yang holistik (komprehensif).

e. Kebutuhan yang serius untuk mempertimbangkan konteks dan latar belakang budaya klien, mengimplikasikan bahwa konselor harus memperhatikan secara sungguh-sungguh tentang peranan agama dalam budaya. Keyakinan dan praktik beragama merupakan aspek fundamental dalam budaya klien (Yusuf Dan A. Juntika Nursihan, 2009: 134).

Ditegaskan pula oleh Surya bahwa salah satu tren bimbingan dan konseling saat ini adalah bimbingan dan konseling spiritual. Tren bimbingan ini berangkat dari kehidupan modern dengan kehebatan ilmu pengetahuan dan teknologi serta kemajuan ekonomi yang dialami bangsa-bangsa barat yang ternyata telah menimbulkan berbagai suasana kehidupan yang tidak memberikan kebahagiaan batiniah dan berkembangnya rasa kehampaan. Dewasa ini, muncul kecenderungan menata kehidupan yang berlandaskan nilai-nilai spiritual. Kondisi ini telah mendorong berkembangnya bimbingan 
dan konseling yang berlandaskan spiritual atau religi (Sutima, 2013: 48).

Bahwa bukan hanya warga Amerika saja yang saat ini membutuhkan perhatian terhadap aspek spiritual dan agama. Para konselor harus mempersiapkan konseling dengan memperhatikan masalah spiritual dan agama. Konselor harus mempersiapkan pelayanan bagi klien yang memiliki perspektif tentang agama dan spiritual sebagai sumber penyembuhan (healing) di dalam kehidupan mereka (Nursalim, 2014: 145).

Hal demikian karena dengan keyakinan beragama berkontribusi positif terhadap kesehatan mental. Artinya, agama dapat digunakan oleh klien sebagai upaya menunjang kesehatan mental (Yusuf Dan A. Juntika Nursihan, 2009: 134). Hal ini didasarkan bahwa agama Islam dalam menghadapi kesehatan mental manusia berperan sebagai berikut:

a. Ajaran Islam beserta seluruh petunjuk yang ada di dalamnya merupakan penawar bagi segala jenis penyakit hati yang ada dalam jiwa manusia.

b. Ajaran Islam memberikan bantuan kejiwaan kepada manusia dalam menghadapi cobaan dan mengatasi kesulitan.

c. Ajaran Islam memberikan rasa aman dan tenteram yang menimbulkan keimanan kepada Allah dalam jiwa seorang mukmin.

d. Bagi seorang muslim, ketenangan jiwa, rasa aman, dan ketenteraman jiwa akan terealisasi dengan keimanannya kepada Allah yang akan membekali harapan kan pertolongan, lindungan dan penjagaanNya (Sutima, 2013, 163-164.).

Dimensi spiritual pada manusia menunjukkan bahwa manusia pada hakikatnya adalah makhluk religious, manusia sebagai makhluk yang bertuhan. Hal ini mengisyaratkan bahwa manusia memiliki ketinggian derajat dibandingkan makhluk tuhan lainnya, hal ini sekaligus menunjukkan bahwa manusia mengemban tugas sebagai khalifah Allah di bumi. Karena kemuliaannya, maka manusia harus mampu semaksimal mungkin untuk memuliakan dirinya. Sehingga dalam manusia menjalankan amanahnya sebagai pemimpin harus dengan penuh kemuliaan. 


\section{Implementasi Landasan Religius dalam Kegiatan Bimbingan ...}

Setiap manusia adalah pemimpin, terutama menjadi pemimpin untuk dirinya sendiri. Dalam memikul amanah yang telah Allah berikan tersebut, manusia dibekali oleh Allah dengan beberapa keistimewaan. Sebagaimana dijelaskan dalam al Qur'an surat at Tin ayat 95 bahwa manusia adalah makhluk yang terbaik, indah dan sempurna: "Sesungguhnya Kami telah menciptakan seorang manusia dengan sebaik-baik bentuk". Kemuliaan yang ada dalam diri manusia perlu dikembangkan dan dimuliakan melalui berbagai upaya diantaranya melalui pendidikan dan bimbingan.

Landasan religious dalam bimbingan dan konseling ditekankan pada tiga hal pokok, yakni: 1) Keyakinan bahwa manusia dan seluruh alam semesta adalah makhluk Allah. 2) Sikap yang mendorong perkembangan dan perikehidupan manusia berjalan ke arah dan sesuai dengan kaidah-kaidah agama. 3) Upaya yang memungkinkan berkembang dan dimanfaatkannya seecara optimal suasana dan perangkat budaya (termasuk ilmu pengetahuan dan teknologi) serta kemasyarakatan yang sesuai dan meneguhkan kehidupan beragama untuk membantu perkembangan dan pemecahan masalah individu (Tohirin, 2011: 97).

\section{Manusia sebagai Makhluk Tuhan}

Tuhan memberi kepercayaan kepada manusia untuk menjadi khalifah, terutama menjadi pemimpin bagi dirinya sendiri. Tugas ini menjadi tugas yang paling mendasar, karena jika untuk memimpin dirinya sendiri saja tidak mampu, maka itu artinya kehidupan manusia dan kemanusiaan manusia akan hancur. Sebaliknya, jika manusia sanggup untuk memimpin dirinya sendiri, itu artinya ia mampu untuk menjadi pemimpin bagi makhluk Tuhan yang lainnya. Ketika manusia berhasil memimpin dirinya sendiri maka akan mewujudkan kemuliaan kemanusiaan yang mengantarkannya pada kemuliaan makhluk Tuhan yang lainnya (Prayitno Dan Erman Amti, 1998: 146-147).

\section{a. Sikap Keberagamaan}

Pada setiap diri manusia dari zaman ke zaman selalu dijumpai praktik-praktik kehidupan keagamaan. Kehidupan keagamaan yang semula dianggap sesuatu yng sacral karena segala sesuatunya didasarkan pada firman Tuhan dapat merosot menjadi 
sekedar upacara rutin belaka. Sikap kemerosotan dan pengabaian nilai-nilai agama akan mengakibatkan kemerosotan kemuliaan kehidupan manusia dipandang dari tuntutan Tuhan berdasarkan firman-firmannya. Kemajuan ilmu pengetahuan dan teknologi tidak akan mampu mengatasi pemerosotan tersebut, namun justru semakin memperparah. Sikap keberagamaan menjadi tumpuan bagi keseimbangan hidup di dunia dan akhirat. Agama yang berketuhanan yang Maha Esa memadukan secara dinamis keterkaitan kehidupan dunia dan akhirat yang kaidah-kaidahnya mampu diterapkan oleh manusia dengan ciri-ciri keberadaannya itu. Agama seperti itulah yang hendaknya menjadi isi dari sikap keberagamaan. Penyikapan yang dimaksud itu pertama difokuskan kepada agama itu sendiri yakni penyikapan yang tidak merendahkan atau mengabaikan agama. Karenanya, kaidah-kaidah agama harus diresapi dan diamalkan sebagai petunjuk, pembeda, dan pembimbing kemuliaan akhlak dan perilaku (Prayitno Dan Erman Amti, 1998: 149-150).

Kedua, penyikapan yang menyerapkan segenap upaya manusia dalam peningkatan ilmu dan teknologi, ditundukkan pada tuntutan keserasian hidup di dunia dan akhirat. Keyakinan bahwa Tuhan adalah benar, dan ilmu pengetahuan dan teknologi adalah upaya dan menerapkan kebenaran, maka tidak perlu ada pertentangan antara agama dan iptek. Penyikapan yang demikian justru menjadikan kemajuan ilmu pengetahuan dan teknologi sebagai wahana peningkatan kemuliaan manusia yang berdimensi dunia dan akhirat. Pegembangan ilmu dan teknologi dihayati dan dimanfaatkan sebesar-besarnya bagi kesejahteraan dan kemuliaan manusia sesuai dengan tuntutan dan tuntunan agama (Prayitno Dan Erman Amti, 1998: 151).

\section{b. Peranan Agama}

Landasan religious dalam bimbingan dan konseling menghendaki klien sebagai makhluk Tuhan dengan segenap kemuliaan kemanusiaannya menjadi fokus netral upaya bimbingan dan konseling. Oleh karenanya, dalam melakukan proses bimbingan dan konseling harus dengan menghadirkan suasana yang sarat akan kemuliaan kemanusiaan pula. Kemuliaan kemanusiaan manusia 


\section{Implementasi Landasan Religius dalam Kegiatan Bimbingan ...}

diungkapkan melalui ajaran agama (Prayitno Dan Erman Amti, 1998: 154).

Agama memberikan dampak yang cukup berarti dalam kehidupan manusia, termasuk dalam hal kesehatan. Menurut Guire, agama sebagai sistem nilai berpengaruh dalam kehidupan masyarakat modern dan berperan dalam membuat perubahan sosial. Layaknya institusi sosial lainnya, agama berperan besar dalam perubahan sosial. Agama juga menunjukkan kemampuan adaptasi dan vital dalam berbagai segi kehidupan sosial, hingga perubahanperubahan dalam struktur sosial dalam skala besar tak jarang berakar dari pemahaman terhadap agama (Jalaludin, 2012: 155).

Hubungan spiritual manusia dengan penciptanya ketika beribadah akan memunculkan kekuatan spiritual berupa limpahan ilahiah atau petikan spiritual berupa al hikmah. Tekad bertambah kuat, kemauannya semakin keras, dan semangatnya kian meningkat sehingga ia pun lebih memiliki kesiapan untuk menerima ilmu pengetahuan atau hikmah (Nursalim, 2015: 149).

Pentingnya menghadirkan agama (Islam) sebagai sistem kehidupan karena peradaban modern yang didominasi peradaban barat telah gagal menyejahterakan aspek moral-spirital manusia. Menurut Erich Fromm, ${ }^{1}$ bahwa manusia modern mengalami suatu ironi. Manusia modern memang berjaya dalam hal material, namun mereka merasakan keresahan jiwa. Mereka rentan terhadap stress, depresi, teralienasi, mengalami berbagai penyakit kejiwaan, hingga memutuskan untuk bunuh diri. (Nashari, 2010: 12). Ini artinya, kejayaan yang dicapai dan diraih seseorang dalam hal material tidak selalu menjamin orang tersebut untuk hidup bahagia, tenteram dan sejahtera.

Agama adalah suatu system yang berdimensi banyak. Agama dalam pengertian Glock \& Strk adalah sistem symbol, sistem keyakinan, sistem nilai dan sistem perilaku yang terlembagakan, yang semuanya berpusat pda persoalan-persoalan yang dihayati sebagai yang paling maknawi (Ancok dan Fuat Nashari Suroso, 2011: 76).

${ }^{1}$ Seorang psikolog Amerika 
Islam menyuruh umatnya untuk beragama secara menyeluruh. Setiap muslim, baik dalam berpikir, bersikap maupun bertindak, diperintahkkan untuk berislam. Dalam melakukan aktivitas ekonomi, social, politik atau aktivitas apapun, seorang muslim diperintahkan untuk melakukannya dalam rangka beribadah kepada Allah. Dimanapun dan dalam keadaan apapun, setiap muslim hendaknya berislam (Ancok dan Fuat Nashari suroso, 2011: 78). Demikian halnya dalam aktivitas/ bidang pendidikan, siapapun yang terlibat di dalamnya dihimbau untuk berislam. Dalam hal ini, pemberian bimbingan dan konseling di dasarkan atas ajaran agama Islam, terutama dalam menangani dampak puber pada peserta didik.

Esensi islam adalah tauhid atau pengesaan Tuhan, tindakan yang menegaskan Allah sebagai yang Esa, Pencipta yang mutlak dan transenden, penguasa segala yang ada. Tidak ada satupun perintah dalam islam yang bisa dilepaskan dari Tauhid (ancok dan Fuat Nashari suroso, 2011: 78-79).

Ketika manusia beragama, itu artinya manusia memiliki Tuhan sehingga kita harus selalu mendekat kepadanya. Karena pada dasarnya, ketika manusia menjauhkan diri dari Tuhan, itu artinya nilai-nilai agama tidak ada dalam dirinya. Hal ini yang menyebabkan manusia dalam keadaan merugi. "Mereka Itulah orang yang membeli kesesatan dengan petunjuk, maka tidaklah beruntung perniagaan mereka dan tidaklah mendapat petunjuk" (Q.S 2:16). "Ingatlah, hanya dengan mengingat Allah hati menjadi tenteram." (Q.S 13:28) (Jalaludin, 2012: 176).

Fakta yang terjadi adalah agama hanya dianggap sebagai anutan, sesuatu yang datang dari luar dan asing. Padahal potensi agama sudah bersemi dalam batin sebagai fitrah manusia. Potensi yang ditelantarkan oleh keangkuhan egoisme manusia, maka jalinan keharmonisan antara kebutuhan fisik dan mental spiritual terputus terputus. Akibatnya manusia kehilangan kemampuan untuk mengenal dirinya. Menyelami potensi diri sebagai makhluk beragama (Jalaludin, 2012: 175).

Orang yang di dalam hatinya tidak ada ketenangan dan ketenteraman adalah orang yang sakit rohani atau mentalnya, tuls $\mathrm{H}$. Carl Whiterington. Para ahli psikiatri meyakni bahwa setap manusia memiliki kebutuhan-kebutuhan dasar yang diperlukan untuk 


\section{Implementasi Landasan Religius dalam Kegiatan Bimbingan ...}

melangsungkan proses kehidupan secara lancar. Kebutuhan tersebut dapat berupa kebutuhan jasmani, rohani maupun sosial. Bila kebutuhannya tidak terpenuhi, maka ia akan berusaha menyesuaikan diri dengan kenyataan yang dihadapinya. Kemampuan menyesuaikan diri ini akan mengembalikan ke kondisi semula hingga proses kehidupan berjalan lancar seperti apa adanya. Namun tak jarang dijumpai bahwa seorang tak mampu menahan keinginan bagi terpenuhinya kebutuhan dirinya. Kondisi ini mengakibatkan pertentangan (konflik) dalam batin. Pertentangan ini menimbulkan ketidakseimbangan dalam kehidupan rohani yang dalam kesehatan mental disebut jejusutan rohani (kekusutan fungsional) (Jalaludin, 2012: 176). Kondisi demikian adalah sebagai dampak yang muncul ketika manusia melepaskan diri dari agama, sehingga nilai-nilai agama tidak melekat dalam dirinya.

\section{Bimbingan dan Konseling}

Bimbingan dan pendidikan keduanya adalah identik. Artinya ketika seseorang melakukan bimbingan, maka ia juga sedang melakukan kegiatan mendidik, dan sebaliknya ketika seseorang melakukan kegiatan mendidik maka ia juga sedang melakukan kegiatan membimbing. Beberapa alasan yang mendasari perlunya bimbingan dan koseling dalam dunia pendidikan. Pertama, perkembangan Ilmu Pengetahuan dan Tekonologi (IPTEK). Perkembangan iptek berdampak pada kehidupan individu, baik sebagai pribadi maupun sebagai anggota masyarakat. Individu dihadapkan pada situasi yang serba cepat dan kompleks. Berbagai persoalan yang dihadapi antara lain: jenis dan pola kehidupan, hubungan sosial antar individu, kesempatan memperoleh pendidikan, kesempatan memperoleh pekerjaan, persaingan antar individu. Dalam kondisi tersebut, individu dituntut menyesuaikan diri (adaptasi), perencanaan dan pemilihan pendidikan, perencanaan dan pemilihan pekerjaan, masalah hubungan sosial, keluarga, masalah-masalah pribadi dan lain sebagainya. Oleh karenanya, lembaga pendidikan tidak dapat melepaskan diri dari situasi kehidupan tersebut. Sehingga lembaga pendidikan memiliki tanggung jawab untuk membantu para siswa, baik sebagai pribadi maupun sebagai calon anggota masyarakat. Guru, sesuai fungsinya 
sebagai pembimbing dituntut untuk membantu memecahkaan berbgai persoalan yang dihadapi peserta didik (Tohirin, 2011: 3-4).

Kedua, makna dan fungsi pendidikan. Kebutuhan akan layanan bimbingan dan konseling dalam pendidikan berkaitan erat dengan hakikat makna dan fungsi pedidikan dalam keseluruhan aspek kehidupan. Pendidikan sebagai proses membantu individu baik jasmani maupun rohani ke arah tebentuknya kepribadian utama. Pendidikan pada hakikatnya merupakan upaya untuk membentuk manusia yang lebih berkualitas, yaitu pribadi yang serasi, selaras dan seimbang dalam aspek spiritual, moral, sosial, intelektual, fisik, dan sebagainya. Pribadi yang berkualitas disebut sebagai insan kaffah (insan kamil) yaitu sosok pribadi yang sehat jasmani dan rohaninya, dapat mengimplementasikan iman, ilmu dan amal serta zikir dalam kehidupan sehari-hari dalam rangka mencapai kebahagiaan dunia dan akhirat. Tujuan tersebut yang ingin dicapai pula oleh layanan bimbingan dan konseling. Karenanya, kegiatan pendidikan hendaknya diarahkan untuk tercapainya pribadi-pribadi yang berkembang optimal, kegiatan pendidikan hendaknya bersifat menyeluruh dan tidak hanya instruksional belaka, tetapi meliputi kegiatan yang menjamin bahwa setiap peserta didik secara pibadi memperoleh layanan sehingga akhirnya dapat berkembang secara optimal. Dalam kaitan ini, bimbingan dan konseling beperan sangat penting dalam pendidikan, yaitu membantu setiap pribadi peserta didik agar berkembang secra optimal (Tohirin, 2011: 4-6).

Ketiga, guru. Tugas dan tanggung jawab guru sebagai pendidik adalah mendidik dan mengajar, yakni membantu peserta didik mencapai kedewasaan. Fungsi guru sebagai pengajar dan pembimbing yakni memahami semua aspek pribadi peserta didik baik fisik maupun psikis. Guru hendaknya memahami tingkat perkembangan peserta didiknya meliputii kebutuhan pribadi, kecakapan, kesehatan mentalnya. Salah satu peran guru secara psikologis yaitu sebagai petugas kesehatan mental, yakni bertanggung jawab terhadap pembinaan kesehatan, khususnya kesehatan mental siswa. Guru juga berperan sebagai direktur pembelajaran, yakni guru mengarahkan aktivitas siswa sehingga terjadi proses belajar dalam kegiatan pembelajaran. Dalam proses tersebut, guru mengubah perilaku pserta didik agar terjadi 


\section{Implementasi Landasan Religius dalam Kegiatan Bimbingan ...}

perubahan dalam perilakunya untuk menjadi lebih baik. Untuk menjalankan peran-peran diatas, guru harus menguasai bimbingan dan konseling, dengan didasarkan pada tiga alasan. Pertama, pendidikan pada hakikatnya merupakan usaha sadar untuk mengembangkan kepribadian individu. Hal ini berimplikasi bahwa dalam proses pendidikan menuntut adanya pendekatan pribadi melalui layanan bimbingan dan konseling. Kedua, pendidikan senantiasa berkembang secara dinamis, karenanya selalu terjadi perubahan-perubahan dan penyesuaian dalam berbagai komponennya. Dalam menghadapi perkembangan ini, siswa mmerlukan bantuan dalam penyesuaian diri melalui layanan bimbingan dan konseling. Ketiga, pada hakikatnya guru mempunyai peranan yang luas tidak hanya sebagai pengajar tapi juga sebagai pendidik. Sebagai pendidik, guru seyogyanya dapat menggunakan berbagai pendekatan, diantaranya pendekatan pribadi dalam mendidik siswanya (Tohirin, 2011: 4-6).

Keempat, faktor psikologis. Siswa merupakan pribadi yang unik dengan segala karakteristkya. Sebagai individu yang sedang berkembang, siswa memiliki kebutuhan dan dinamika dalam interaksi dengan lingkungannya. Juga terdapat perbedaan individual antara siswa yang satu dengan lainnya serta terjadi perubahan perilaku sebagai akibat hasil proses belajar yang telah dilakukan oleh siswa. Aspek psikologi tersebut dapat menimbulkan berbagai masalah psikologis yang menuntut adanya pemecahan melalui pendekatan psikologis antara lain melalui layanan bimbingan dan konseling (Tohirin, 2011: 8-9).

Kelima, masalah belajar. Kegiatan belajar merupakan inti dari kegiatan proses pendidikan secara keseluruhan di madrasah. Siswa sebagai pelajar akan banyak dihadapkan pada persoalan-persoalan belajar. Diantara masalah belajar yang dihadapi siswa meliputi pengaturan waktu belajar, memilih cara belajar yang tepat, menggunakan buku-buku pelajaran, belajar berkelompok, memilih mata pelajaran yang cocok, memilih studi lanjutan, kesulitan konsentrasi, mudah lupa, mempersiapkan ujian dan lain sebagainya (Tohirin, 2011: 11).

Beberapa alasan yang mendasari perlunya bimbingan dan konseling dalam pendidikan tersebut menunjukkan bahwa kegiatan 
bimbingan dan konseling perlu dilakukan di lembaga pendidikan, mengingat bahwa dalam lembaga pendidikan ada unsur siswa yang sudah pasti memerlukan peranan bimbingan dan konseling.

Bimbingan didefinisikan sebagai proses membantu individu untuk memahami diri dan lingkungannya. Kata kunci dalam definisi tersebut adalah poses. Proses diartikan sebagai gejala yang memperlihatkan perubahan terus menerus dari waktu ke waktu. Kata proses dalam konteks ini menyatakan bahwa bimbingan melibatkan serangkaian tindakan atau langkah-langkah progresif menuju pencapaian tujuan tertentu. Kata kunci yang kedua adalah bantuan. Bantuan adalah bentuk bimbingan atau pertolongan. Dalam konteks klinis atau intervensi psikologis, bantuan atau pertolongan memiliki tujuan untuk melakukan pencegahan, perbaikan dan perbaikan kesulitan (Nursalim, 2015: 18-19).

Konseling adalah hubungan yang terjaln secara profesionl dan pribadi antara konselor dan klien dengan maksud mendorong perkembangan pribadi klien dan membantu menemukan solusi atas permasalahan yang sedang dihadapi klien (Nursalim, 2015: 19). Dalam model pegembangan diri yang dikeluarkan oleh pusat kurikulum balitbang, konseling didefinisikan sebagai pelayanan terhadap peserta didik untuk membantu mereka mencapai kemandirian dan berkembang secara optimal dalam hubungannya dengan kehidupan priadi, akademik, sosial, dan karier. Pelayanan ini dilaksanakan melalui berbagai jenis layanan dan kegiatan pendukung berdasarkan norma-norma yang berlaku (Nursalim, 2015: 20).

Tujuan bimbingan dan konseling pda dasarnya adalah apa yag tersurat dalam definnisi bimbingan dan konseling tersebut. Sebagaimana definisi bimbigaan dari shertzer \& Stone bahwa definisi bimbingan membanu peserta didik agar memhami diri dn lingkungannya jelas merupakan tujuan yang ingin dicapai dai setiap kegiatan bimbigan. Peserta didik harus memahami diri dan lingkungan didasarkan pada asumsi bahwa individu yang memahami dirinya sendiri dan lingkungannya akan dapat bertindak dengan cara lebih efektif, efisie, produktif da pada akhirnya menjadi manusia yang sejahtera (bahagia) dalam hidupnya. (Nursalim, 2015: 21). 


\section{Implementasi Landasan Religius dalam Kegiatan Bimbingan ...}

Carl Rogers ${ }^{2}$ berpendapat bahwa tujuan bimbingan dan konseling adalah untuk meningkatkan perkembangan pribadi dan pertumbuhan psikologi klien. Pendekatan psikologi adalah pendekatan yang lebih memanusiakan manusia. Pendekatan ini mengakui bahwa setiap manusia memiliki kemampuan untuk mengarahkan dirinya sendiri jika berada pada konteks lingkungan yang tepat/ kondusif untuk mendorong perkembangannya (Nursalim, 2015: 21). Pendekatan psikologi digunakan sebagai pendekatan dalam kegiatan bimbingan dan konseling dalam menangani dampak masa puber siswa. Dalam praktiknya, bimbingan dan konseling diupayakan untuk membantu memecahkan permasalahan yang dihadapi siswa, terutama masalah yang timbul dari masa puber.

Fungsi perbaikan dalam bimbingan dan konseling adalah fungsi BK dalam membantu peserta didik mengatasi berbagai permasalahan yang dihadapi. Keberadaan BK di sekolah diharapkan dapat membantu peserta didik menangani atau memecahkan berbagai kesulitan yang dihadapinya, baik terkait kesulitan pribadi, akademik, sosial, maupun karier. Meskipun telah dilakukan berbagai upaya pencegahan, tidak berarti semua peserta didik dapat terhindar dari individu yang menunjukkan perilaku yang mengindikasikan kesulitan. Fungsi penanganan dapat diwujudkan melalui layanan konseling, layanan konsultasi, atau layanan bimbingan kelompok (Nursalim, 2015: 23).

\section{Masa Puber}

Masa puber adalah periode tumpag tindih karena mencakup tahun-tahun akhir masa anak-anak dan tahun-tahun awal masa remaja. Sampai matang secara seksual, ia dikenal sebaga "anak puber", tetapi setelah matang secara seksual, anak dikenal sebagai remaja atau remaja muda. Masa puber adalah periode yang singkat, hanya sekitar 2-4 tahun. Kelompok anak perempuan lebih cepat matang masa pubernya dibanding anak laki-laki (Ridwan, 1998: 115).

Masa puber dibagi dalam tahap-tahap: pra puber, puber, dan pascapuber.

\footnotetext{
2 Seorang Ahli Bimbingan Dan Konseling Dari Pendekatan Humanistik
} 
Tahap prapuber tumpang tindih dengan satu atau dua tahun terakhir masa anak-anak, yakni bukan lagi seorang anak tetapi belum juga sebagai remaja. Tahap pascapuber tumpang tindih dengan tahun pertama atau kedua masa remaja. Masa puber merupakan masa pertumbuhan dan perubahan yang pesat, yang ditandai oleh perrtumbuhan pesat dan perubahan mencolok dalam proporsi tubuh. Perubahan-perubahan ini menimbulkan keraguan, perasaan tidak mampu dan tidak aman, dan dalam banyak kasus mengakibatkan perilaku yang kurang baik.

Masa puber merupakan fase negatif. Individu mengambil sikap "anti" terhadap kehidupan atau kelihatannya kehilangan sifatsifat baik yang sebelumnya telah berkembang, tetapi berlangsung dengan singkat. Fase negatif pada puber lebih menonjol pada anak perempuan daripada anak laki-laki.

Beberapa akibat yang timbul dari masa puber dan implementasi lndasan religious dalam menanganinya adalah sebagai berikut:

a. Ingin menyendiri

Dimulainya masa puber mengakibatkan anak menarik diri dari teman-teman dan keluarganya. Anak tidak ada keinginan untuk berinteraksi dan bersosialisasi, baik dengan teman maupun dengan anggota keluarganya. Hal yang dilakukan ketika anak sudah mengasingkan diri adalah melamun, merenung tentang perasaannya yang tidak dimengerti dan tidak diperlakukan dengan baik oleh lingkungan sekitar.

Mengasingkan diri adalah suatu hal yang tidak baik. Mengasingkan diri berarti memilih untuk sendiri dan tidak menginginkan kebersamaan. Padahal dengan menarik diri dari orang yang ada di sekitar, itu artinya memperlemah jalinan silaturahim. Sedangkan dalam agama islam, menjalin silaurahim adalah suatu hal yang sagat dianjurkan. Hal ini sebagaimana dijelaskan di dalam surat an nisa ayat 1 yang artinya: "dan bertakwalah kepada Allah dengan mempergunakan namaNya kamu saling meminta satu sama lain, dan (peliharalah) hubungan silaturrahim. Sesungguhnya Allah selalu menjaga dan mengawasi kamu."

Dari ayat diatas dapat diketahui bahwa agama islam sangta menganjurkan untuk smemperkuat silaturahim. Dengan demikian, 


\section{Implementasi Landasan Religius dalam Kegiatan Bimbingan ...}

meskipun dalam keadaan puber, siswa tidak harus dalam keadaan menyendiri tetapi harus tetap menjalin silaturahim dengan orang sekitar.

b. Bosan

Anak yang sedang puber mudah sekali untuk merasakan kejenuhan dan kebosanan, jenuh pada tugas-tugas sekolah, kegiatankegiatan sosial dan bahkan pada hal yang sebelumnya sangat digemari dan disukainya. Akibat yang timbul dari kebosanan ini adalah anak menjad pasif, dan hal ini mangakibatkan prestasi anak di berbagai bidang menurun. Akibat dari ketiadaan prestasi yang diraihnya, anak merasa rendah diri.

Jenuh dan bosan adalah penyakit hati. Kejenuhan dan kebosanan dalam belajar menyebabkan anak menjadi pasif, dan malas untuk melakukan suatu aktivitas. Ketika hal ini terjadi, tentunya akan mengganggu prestasi belajar anak yang bersangkutan. Dalam agama Islam, jenuh dan bosan adalah dua hal yang harus dihindari. Hal ini sebagaimana dijelaskaan dalam surat Al Ar Rad: 11 yang artinya: "sesungguhnya Allah tidak akan mengubah nasib suatu kaum hingga mereka mengubah diri mereka sendiri".

c. Inkoordinasi

Pertumbuhan pesat dan tidak seimbang mempengaruhi pada koordinasi gerakan, dan anak akan merasa kikiu dan janggal selama beberapa waktu. Setelah pertumbuhan melambat, koordinasi akan membaik secara bertahap.

Dalam suatu organisasi, koordinasi adalah sangat diperlukan. Untuk mencapai tujuan bersama, setiap anggota dalam suatu organisasi harus saling koordinasi antara satu dengan lainnya. Koordinasi diperlukan untuk mencapai kesepakatan dan keputusan bersama. Sebagaimana di dalam agama islam, bahwa musyawarah untuk mufakat adalah suat hal yang sangat dianjurkan. Oleh karenanya, meskipun dalam keadaan puber siswa tetap harus melakukan koordinasi untuk mencapai kesepakatan bersama. Hal ini sebagaimana dijelaskan dalam Q.S al Imran ayat 159: "maka disebabkan rahmat Allahlah kamu berlaku lemah lembut terhadap mereka. Sekiranya kamu bersikap keras lagi berhati kasar, tentulah mereka menjauhkan diri dari sekelilingmu. Karena itu maafkanlah mereka, mohonkanlah ampun bagi mereka, dan bermusyawarahlah 
dengan mereka dalam urusan itu. Kemudian apabila kamu telah membulatkan tekad, maka bertawakallah kepada Allah. Sesungguhnya Allah menyukasi orang-orang yang bertawakkal kepadaNya".

d. Antagonisme sosial

Anak puber memiliki keegoisan yang tinggi, seringkali membantah dan menentang pada sesuatu yang tidak disukainya/ tidak sesuai dengan jalan pikirannya. Dari keegoisan ini pada akhirnya menimbulkan permusuhan.

Egois artinya mementingkan diri sendiri, yakni mementingkan keinginan dan kemauan diri sendiri. Orang yang egois hanya akan peduli pada dirinya sendiri, bukan orang lain. Ketika keegoisan sudah tertanam dalam diri, ia akan mengabaikan keadaan sekitar dan tidak memperdulikan orang lain yang ada di sekitarnya. Hal yang dikhawatirkan adalah bahwa apa yang diinginkannya tidaklah pasti baik dan benar. Karena pada dasarnya agama menganjurkan untuk menghargai dan menghormati satu sama lainnya. Oleh karenanya, keegoisan pada diri siswa harus ditinggalkan.

e. Emosi yang meninggi

Anak yang sedang puber mudah sekali untuk untuk mengalami kemurungan, merajuk, ledakan amarah dan kecenderungan untuk menangis karena hasutan yang sangat kecil merupakan ciri-ciri bagian awal masa puber.

Amarah adalah sifat yang dikendalikan oleh setan. Ketika seseorang sedang marah, itu artinya ia sedang tidak bisa mengendalikan dirinya, dan tidak mampu mengontrol dirinya. Ketika seseorang sedang marah, maka jiwanya tidak merasa tenang dan selalu merasa gelisah. Dalam agama islam, salah satu upaya yang dapat dilakukan untuk menghindari amarah adalah dengan berwudlu dan memperbanyak membaca istighfar. Dengan berwudlu, maka hati akan kembali menjadi tenang karena ia dalam keadaan suci. Selain itu kita juga harus meyakini bahwa dengan melampiaskan amarah, masalah akan terselesaikan. Justru sebaliknya, amarah hanya akan memperburuk dan memperparah suasana. Oleh karenanya, sebisa mungkin kita harus mengendalikan diri kita agar tidak diliputi dan dikendalikan amarah. 


\section{Implementasi Landasan Religius dalam Kegiatan Bimbingan ...}

\section{f. Hilangnya kepercayaan}

Ketika mengalami masa puber, kepercayaan diri pada anak menurun drastis meskipun sebelumnya anak itu memiliki kepercayaan yang tingi. Anak yang puber juga takut pada kegagalan karena daya tarik menurun dan karena kritik yang datang dari orang tuanya. Karenanya perasaan rendah diri banyak muncul dari mereka yang telah melewati masa puber.

Hilangnya kepercayaan diri pada anak yang sedang puber akan mengakibatkan ia merasa rendah diri. Ketika anak sudah rendah diri, maka anak tersebut merasa tidak memiliki kemampuan dalam dirinya. Hal demikian harus segera diatasi karena akan mengganggu presatasi belajarnya. Karena pada dasarnya mereka yang percaya diri adalahh mereka yang menganggap dirinya ada, dan mempunyai kemampuan.

Sebagaimana dijelaskan dalam ayat berikut:

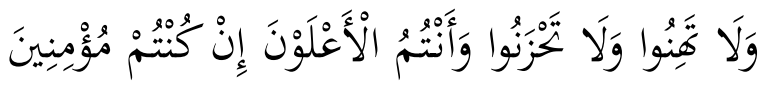

"Janganlah kamu bersikap lemah, dan janganlah (pula) kamu bersedih hati, padahal kamulah orang-orang yang paling tinggi (derajatnya), jika kamu orang-orang yang beriman." (Ali Imran : 139).

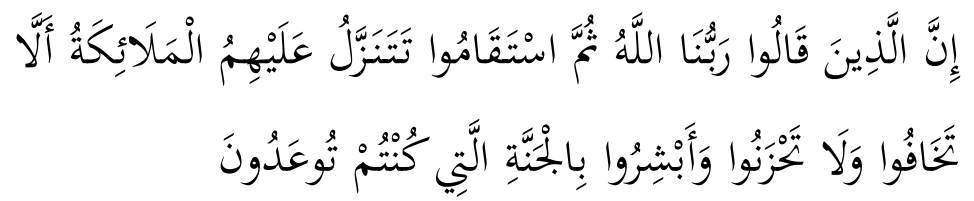

"Sesungguhnya orang-orang yang mengatakan: "Tuhan kami ialah Allah" kemudian mereka meneguhkan pendirian mereka, maka malaikat akan turun kepada mereka (dengan mengatakan): "Janganlah kamu merasa takut dan janganlah kamu merasa sedih; dan bergembiralah kamu dengan (memperoleh) surga yang telah dijanjikan Allah kepadamu." (Fusshilat : 30).

g. Terlalu sederhana

Akibat dari masa puber, anak berubah menjadi sosok yang sederhana. Kesederhanaan ini akan nampak dalam hal penampilan. Hal ini karena ia takut orang lain akan memperhatikan perubahan yang dialaminya dan memberikan komentar yang buruk. Karenanya, anak akan lebih memilih untuk berpenampilan yang sederhana 
daripada harus menerima kritik dari perubahan yang dialaminya. (Ridwan, 1998: 119-120).

Perilaku sederhana yang meliputi anak yang sedang puber mengakibatkan mereka tidak mampu dan tidak percaya diri untuk menunjukkan kemampuan-kemampuan yang dimilikinya. Sederhana dalam hal berpakaian dikhawatirkan akan berakibat pada ketidakrapian dalam mengenakan seragam. Yang harus dipahami bahwa penampilan yang indah tentu disukai. Sebagaimana Allah pun disifati dengan keindahan. Sebagaimana sabda Rasulullah saw:

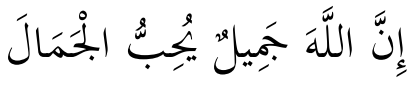

"Sesungguhnya Allah itu indah, menyukai keindahan" [H.R. Muslim, dari sahabat Abdullah bin Mas'ud]

Dari hadits ini, kita paham bahwa Allah mencintai keindahan. Allah menyukai hamba-Nya yang berpenampilan rapi, indah, dan bersih. Namun sebaliknya, Allah tidak menyukai orang yang berpenampilan terlalu sederhana dan tidak rapi.

\section{Simpulan}

Landasan religious adalah sebagai upaya mengintegrasikan nilai-nilai agama dalam proses bimbingan dan konseling. Tujuan yang hendak di capai dalam penerapan landasan religious bimbingan dan konseling adalah menempatkan siswa sebagai makhluk Tuhan dengan segenap kemuliaannya. Hal ini karena beragama berkontribusi positif terhadap kesehatan mental. Artinya, agama dapat digunakan oleh klien sebagai upaya menunjang kesehatan mental. Dari sini dapat kita ambil kesimpulan bahwasannya agama dijadikan sebagai landasan dalam proses bimbingan dan konseling dalam menghadapi suatu problematika kehidupan. Agama dijadikan sebagai solusi dalam menghadapi dampak yang ditimbulkan pada saat siswa mengalami puber. Implementasi landasan religious dalam menghadapi masa puber siswa adalah dengan kembali pada $\mathrm{Al}$ Qur'an dan Hadits yang dijadikan sebagai pedoman dalam agama Islam. 


\section{Implementasi Landasan Religius dalam Kegiatan Bimbingan ...}

\section{DAFTAR PUSTAKA}

Djamaldin Ancok Dan Fuat Nashari Suroso. 2011. Psikologi Islam:

Solusi Islam Atas Problem-Problem Psikologi, Yogyakarta, Pustaka Pelajar.xdrtt

Fuad Nashari. 2010. Agenda Psikologi Islami, Yogyakarta, Pustaka Pelajar.

Jalaludin. 2012. Psikologi Agama: Memahami Perilaku Dengan Mengaplikasikan Prinsip-Prinsip Psikologi, Jakarta, PT. Rajagrafindo Persada.

Mochamad Nursalim. 2015. Pengembangan Profesi Bimbingan dan Konseling, Jakarta, Erlangga.

Prayitno Dan Erman Amti. 1998. Dasar-Dasar Bimbingn Dan Konseling, Jakarta Rineka Cipta.

Ridwan. 1998. Penanganan Efektif Bimbingan Dan Konseling Di Sekolah, Yogyakarta, Pustaka Pelajar.

Suryani. Lilis, Syahniar dan Zikra, PENYESUAIAN DIRI PADA MASA PUBERTAS, 2013 KONSELOR | Jurnal Ilmiah Konseling,

Volume 2 Nomor 1 Januari hlm. 136

Sutirna. 2013. Bimbingan Dan Konseling: Pendidikan Formal, Non Formal Dan Informal, Yogyakarta, Andi Offset.

Syamsu Yusuf Dan A. Juntika Nursihan. 2009. Landasan Bimbingan Dan Konseling, Bandung, Remaja Rosdkarya.

Syamsu Yusuf Dan A. Juntika Nursihan. 2009. Landasan Bimbingan Dan Konseling, Bandung, Remaja Rosdakarya.

Tohirin. 2011. Bimbingan Dan Konseling, Jakarta, Rajagrafindo Persada. 